\title{
Nomophobia: Phenomena and Therapy (Analysis in Psychology and Islamic Perspectives)
}

\author{
$1^{\text {st }}$ Dini Permana Sari ${ }^{1}, 2^{\text {nd }}$ Abdul Mujib ${ }^{2}, 3^{\text {rd }}$ Yuminah Rahmatulloh ${ }^{3}$ \\ \{dini_permana18@mhs_uiinjkt.ac.id ${ }^{1}$, abdul.mujib@uinjkt.ac.id², yuminah@uinjkt.ac.id ${ }^{3}$ ) \\ Post Graduate School of Sy arif Hiday atullah State Islamic University, Jakarta, Indonesia, ${ }^{1,2,3}$
}

\begin{abstract}
Nomophobia is dependence on cell phones and excessive anxiety or great worry if someone is away from the smartphone. This is a response to developments in information and communication technology, which makes it easier for people to meet their needs through access to various information. The IDN Time 2019 Survey Report shows $94.4 \%$ of the millennial generation in Indonesia is a generation addicted to the internet. This phenomenon triggers the increasing number of nomophobic sufferers among the younger generation. Meanwhile, the survival of a country depends on its young generation. Therefore, it is necessary to save Indonesia's young generation, by minimizing nomophobia sufferers. This study aims to identify the indications of Nomophobia which include phenomena, indications, and impacts as well as the factors that influence it using a psychological and Islamic perspective. At the end of the discussion, some nomophobia treatments are called Psychotherapy and Islamic Therapy.
\end{abstract}

Keywords: Nomophobia, smartphone, mobile phone, Psychology, Islam.

\section{Introduction}

The development of information and communication technology (ICT) in the world has also had an impact on Indonesia. This advanced technology has been rapidly happening, especially in the last 20 years and it created communication tools including mobile phones or smartphones of various types, namely i-phone, android, etc. With the advancement of information technology, all human needs can be fulfilled by accessing smartphones, from checking the weather; looking for various information and offers; learning, playing, shopping, etc. The role of a smartphone is to facilitate its owner or user to fulfill his or her needs. $[1,2]$ Changes in technology enable us to store, process, and produce the data accurately and on time. These changes also can unite individuals with one another regardless of distance and time. Such changes in technology and communication have provided easiness for its users and influenced individual behavior in society.

Behavior changes caused by advances in ICT have a significant impact in various fields, including in the fields of education, socio-culture, economy, politics, etc. In the world of education, the development of information technology has had a very positive impact. This is indicated by the results of research from several scholars showing that ICT tools can create more effective learning and learning methods, providing convenience in the learning process, both distance learning and classroom learning with e-learning or audio-visual methods. [3, 4] 
The advance of technology has a positive impact in the field of education, and at the same time, it impacts negatively on some students, especially adolescents. This can be shown by the phenomenon of adolescent behavior in schools and several public places, for example on public transportation, in shopping centers, etc. who are always busy with cellphones or smartphones. They bustle with checking email or WA, updating status on Instagram, Facebook, Twitter, etc., and having fun playing online or offline games. The sophistication of mobile phones or smartphones has attracted attention and provided its users' joy. The current behavior is that they, teenagers, are more engrossed in making friends in cyberspace, playing football, chess, war games, and other games all done within its application that has been set in their cellphone. From this phenomenon, students or adolescents are no longer able to get away from their cellphones or smartphones, on grounds of checking and following the status of a person or friend on social media networks, playing games, etc. This ICT has changed the behavior of adolescents in particular and the culture in society in general, thus giving rise to new problems that have an impact on mental health in society.

Problems that arise in society, especially in Indonesia, can be seen from various news on online media, as follows:

a. Every month dozens of teenagers in Bogor experience mental disorders due to gadget addiction. The results of the interview with dr. Ira Safitri at Marzuki Mahdi Hospital, Bogor, stated that during 2019 she had treated between 2 and 3 people (patients due to gadget addiction) who were outpatient every day. ${ }^{1}$

b. Data sources from psychiatric hospital (RSJ) Cisarua, West Java stated that every year, hundreds of people experience mental disorders due to gadgets. On average, in a month, mental hospitals receive two to dozens of gadget addicted patients aged children and adolescents. The number continues to increase because every day there are patients who come for treatment due to addiction to devices. ${ }^{2}$

c. The results of the IDN Times Survey in 2019, stated that of the 63.5 million millennials, $94.4 \%$ of millennials are connected to the internet, so it is called the internet-addicted generation or i-generation. A total of $14.8 \%$ of millennials spend around 11-13 hours per day using the internet, and 34.7 millennials are classified as addicted users. ${ }^{3}$

Based on the data above, it shows that the number of Nomophobia sufferers is increasing so there is a need for alternatives in solving the Nomophobia problem, as a mental illness for today's young generation.

Meanwhile, youth is the backbone of the country, so a failure in the development of adolescents or young people due to nomophobia will affect failure in the future (middle adulthood to the elderly). This means that current failure will have an impact on the failure of the life of a country and nation.

Based on the mentioned background, this paper aims to identify indications of mental illness in society, namely Nomophobia, to determine the impact of the perspective of health

\footnotetext{
${ }^{1}$ Farhan, "Belasan Remaja di Bogor Alami Gangguan Jiwa Akibat Kecanduan Gadget”, berita diakses 25 Oktober 2019 dari https://news.detik.com/berita/d-4749763/belasan-remaja-di-bogor-alami-gangguaniiwa-akibat kecanduan-gadget/

2 Aiman Witiaksono. "Ratusan Jiwa Tergangou Akibat Gadget I Tersulut Gawai. Tergangøu Jiwa." berita diakses 25 Oktober 2019https://www.msn.com/id-id/ekonomi/bisnis/ratusan-jiwa-terganggu-akibatgadget-tersulut-gawai-terganggu-iiwa-\%E2\%80\%93-aiman-1/vp-AAJGyMY

${ }^{3}$ IDN Research Institute," Indonesia Milllenial report 2019”, berita diakses pada 5 November 2019 pada https://www.idntimes.com/indonesiamillennialreport2019
} 
and Islamic sciences, and to seek alternative solutions to problems from the pers pective of health and Is lamic sciences.

\section{The phenomenon of Nomophobia}

Historically, the term Nomophobia was first introduced in a 2008 study by The UK Post Office to investigate the anxiety experienced by mobile phone users.[5] Mobile phones are one of the fastest-growing technologies, as shown by the increase in mobile phone users every year. Ericsson in his research entitled Ericsson Mobility Report said that in 2015, the total number of mobile phone users will exceed the world's population.[6] This means that every teenager or adult will have a smartphone with more than one gadget.

The word Nomophobia stands for no-mobile-phone-phobia, which has a morphological meaning, namely anxiety without a mobile phone. The definition of Nomophobia is a dependency on mobile phones and excessive anxiety or very worried about being away from a mobile phone. This is in line with the term Smartphone Addiction, which is a functional disorder of the limb caused by poisoning something (medicine/food/object) or a pathological condition that cannot stop and constantly use it (smartphone), and unable to judge or differentiate things rationally.[7]

The term Nomophobia in Chinese is Keichu, and it has been categorized as a specific phobia or phobia defined in the Diagnostic and Statistical Manual of Mental Disorders, fifth edition (DSM-5; American Psychiatric Association, 2013). This means that individuals suffer from intense fear or anxiety when they are exposed to certain situations regarding unreachable mobile phones or not having access to their mobile phones.[8]

The phenomenon of Nomophobia is a new phenomenon that has emerged along with the rapid globalization of smartphone technology. A Source of information from liputanenam.com (1/10/2015), shows that the highest number of people with smartphone addiction is in the Asian continent and it is predicted to improve. A survey conducted by Scient Direct explained that $72 \%$ of children aged 11-12 years in South Korea, spend their time using smartphones for 5.4 hours per day. The survey also revealed that the majority of smartphone users are teenagers and $25 \%$ have nomophobia. Even Trendtek news sources (8/6/2017), stated that toddlers aged three and four years spend an average of 6.5 hours per week playing the internet.

SecurEnvoy, a company in London, which is engaged in technology-based security surveyed 1,000 people working in the UK. The survey results showed that $66 \%(=2 / 3)$ of respondents were afraid of losing or not owning a mobile phone, so the identification of nomophobia could be detected in 2008. This survey shows that $70 \%$ of women are more worried about losing their cellphone compared to men $(61 \%)$. However, in terms of ownership of two mobile phones, men were more than women with a ratio of $47 \%$ and $36 \%$.

SecurEnvoy's research classifies nomophobia based on age groups showing that adolescents (18-24 years) are more nomophobic than adults (25-34 years) with a ratio of $77 \%$ and $68 \%$. Research in the following four years showed that nomophobia among men more increased to $66 \%$. This is because men have more than two mobile phones, thus the tendency to misplace the cellphone can happen.

Source viva.co.id (30/7/2019) reported the results of a survey from Techmark's marketing agency, of 2,000 smartphone gadget owners, indicating the fact that gadget users 
frequently check their smartphones up to 1,500 times per day on average. This shows that cellphone users will continue to hold their cellphone at all times, unites with its owners, depends on, and provides comfort when they are with their smartphone. So that the anxiety behavior and even fear of being away from the cellphone will possibly occur in their daily activities due to this dependency.

From the results of these studies, it appears that diseases with this type of anxiety have been worldwide issues and its majority are adolescents or early adulthood, from their teens to thirties. According to $\mathrm{WHO}$, the type of mental disorder with the highest prevalence is anxiety disease. The 2016 data does not specifically mention the types of anxiety, but nomophobia is included in the category of mental disorders with anxiety, which shows a phenomenon that has penetrated the world.

\section{Indication and Impact}

The indication of Nomophobia, according to Yildirim (2015), is a feeling of extreme anxiety in the following conditions:

a. Not being able to communicate

b. Wifi Losing connectedness

c. Not being able to access information

d. Giving up the convenience of being apart from the mobile phone. These situations are the indicators in the measuring instrument of Nomophobia (NMP-Q), which was conducted by several researchers. [5]

Several studies on the negative impact of the sophistication of ICT on adolescent cellphone or smartphone users have been conducted in various countries, including Indonesia. The following is a description of the research results that show the impact of Nomophobia.

The results of research from Duke University in the United States quoted from Halo Sehat.com (25/10/2019) which involved 151 teenagers show that adolescents who play cellphones too often will experience behavioral disorders and symptoms of ADHD or Attention-Deficit Hyperactivity Disorder. Behavioral disorders in adolescents tend to lie easily, fight, and behave badly because without realizing it, the frequency of playing cellphone leads them to lose good self-control and has difficulty in controlling their emotions. This is supported by research conducted by Muyana and Widyastuti (2017) which shows that adolescents are not able to manage themselves in their activities when they are faced with their smartphones. Kim (2018) supported it, that there is a relationship between psychological problems (loneliness and ADHD) and problematic media use (smartphones).[9, 10]

Research on the clinical and demographic profile of social network users has been conducted by King et.al (2017). Experiments were carried out on 113 volunteers, who were divided into 2 groups (experimental and control). The results of the experiment show that women $(69 \%)$ aged 18-29 years are more (unnatural) in using technology (mobile phones or smartphones) than men. Their psychopathological profile was studied and showed anxiety disorder (85\%), panic (49\%), depression (43\%), social phobia (15\%), obsessivecompulsiveness $(13 \%)$, post-traumatic stress $(6 \%)$. and anorexia $(1 \%)$. [11] The results of this study indicate that there is a relationship between mental illness and excessive 
cellphone or smartphone users. The profile shows that there are 8 (eight) psychiatric disorders for excessive cellphone users.

A study was similar to the study above, conducted by Master, K., et al. (2016). The study involved 343 active (excessive) teenage cellphone users, at the Saad Bin Moath School, United Arab Emirates. The results of this study indicate that $60.3 \%$ of students have bad attitudes and $39.7 \%$ are good. The majority of respondents, $94.2 \%$, use one type of cellphone and $90 \%$ of respondents stated that they felt sad, anxious, or angry when their cellphone was taken away or away from the user.[12]

The impact of Nomophobia can be physiological and psychological pathological, this is related to physical damage due to electromagnetic field radiation, car/motorbike accidents, difficulty in using new technology that creates fear of being considered unable to keep up with new technology. Besides, there are social and economic impacts, where there are changes in daily behavior and debt behavior to buy the best / newest smartphone.[13]

Based on some of the research results, surveys, and facts mentioned above, it shows that adolescent cellphone users who actively (excessively) tend to have feelings of sadness, anxiety, or anger because of the fear of losing something close and attached to them, namely mobile phones. Even some teenagers experience anxiety or fear when the cellphone is not working (off) or when the cellphone is not in their hands. Dependent behavior and anxiety that cannot be separated from cellphones are called no-mobile-phone-phobia (Nomophobia).

The results showed that adolescents who are too active in using cellphones or smartphones tend to experience behavioral and mental dis orders including sleep disorders, not being able to manage themselves, psychosomatic, obsessive, addictive, nomophobia, ADHD, etc.[3, 12, 14-16] This means showing mental health problems, physical, sociocultural, and economic inactive smartphone users.

In the Islamic perspective, Nomophobia shows the characteristics of mental illness, this is because of the following indications:

\subsection{Anxiety shows the restlessness of the soul}

This is in contrast to the mutmainah nafs in the QS letter. Al-Fajr [89]: 27-28):

Meaning: "O calm soul, return to your Lord with a satisfied heart that is blessed by Him."

According to the Tafsir Quraish Shihab: O calm or safe soul, it means a soul that believes. Come back to the pleasure of your Lord with a sense of satisfaction with the blessings that have been given to you, and also satisfied with the deeds that you have done. ${ }^{4}$

For people with Nomophobia, will not experience inner calm or peace of mind and will not feel satisfied with the blessings that Allah has given to them.

\subsection{The inability to control oneself that comes from nafs (self) is an indication of a humiliating mental symptom (= mental illness).}

Ar-Razi, as a Muslim philosopher, stated that what distinguishes humans from animals is the mind. Therefore, humans must not be controlled by lust which becomes a disease and a factor that misleads humans. The inability to control lust (for people with nomophobia) is an indication of mental illness in humans.[31]

4 Tafsir Quraish Shihab accessed on 30 November 2019 pada https://tafsira.com/89-al-fajr/ayat28\#tafsir-quraish-shihab and https://tafsirq.com/89-al-fajr/ay at-28\#tafsir-quraish-shihab 


\subsection{Addiction is commensurate with the intoxicating condition}

An intoxicating condition shows unconsciousness, irrationality in thinking. This is analogous to khamr (an intoxicating drink) in QS. Al Maidah: 90

This means: "O you who believe, actually (drinking) khamar, gambling, (sacrificing for) idols, drawing fate with arrows, are among the actions of satan. So stay away from these deeds so that you will have good luck."

This means that smartphones can be haram for nomophobia sufferers because cellphones are equivalent to khamr which can be intoxicating for nomophobia sufferers Therefore we need an Islamic therapeutic approach to overcome this addiction.

\section{Factors Affecting Nomophobia}

Several factors that influence the formation of Nomophobic behavior, according to several previous researchers,[17-21] including:

\subsection{Internal Factors}

This factor is influenced by the factors inherent in a person, including:

\subsubsection{Temperament, characteristics, or personality.}

Individuals with strong personalities tend to be able to minimize nomophobia, and vice versa. Individuals with high novelty-seeking and sensation-seeking temperaments tend to experience nomophobia easily because they are more easily bored (boring) with routine activities, so they will seek new sensations impulsively, enthusiastically, exploratively, and fulfill their curiosity. Individuals with low Self Esteem will assess themselves negatively and tend to feel unsafe when interacting directly socially, so they will feel comfortable when they interact by cellphone. Individuals with low self-control are unable to control themselves in using their smartphones.

This is different from individuals who have cooperative characters, showing socially tolerant, empathic, helpful, and compassion so that they have friends to communicate with psychological maturity. Likewise, the high self-transcendence character has spiritual maturity and the desire to realize the spiritual with meditation activities and nonmaterialistic thoughts. Both of these characters can reduce the tendency of nomophobia.

\subsubsection{Gender and Age Factors}

The results of the research show that there are different levels of nomophobia in men and women, in certain age groups such as adolescents or adults. In adolescence, it shows that girls tend to have a higher level of nomophobia than boys, and the man shows a higher level of nomophobia than women. 


\subsubsection{Psychological factors}

The factors that cause nomophobia are due to certain situations that affect a person's psychological condition, for example, individuals find a sense of psychological comfort when situations are uncomfortable. For example, sadness, loneliness, the boredom of study, anxiety, and lots of free time (leisure boredom).

\subsection{External Factors}

This factor comes from outward of the individual, including high (intense) media exposure about mobile phones and their facilities. This affects social needs by following a lifestyle or needs to be connected to social networks (Connected Presence) with more choices and broader interests, for example, music, films, games, research, videos, photos, and many other choices.

\section{Psychological and Islamic Therapy}

Handling of nomophobia can be done with two approaches, namely a psychological approach, commonly called psychotherapy, and an Islamic approach, commonly called Islamic therapy.

\subsection{Psychological Approach}

This approach is often used by Clinical Psychologists, who are certified as Clinical Psychologists. The results of research on Nomophobia sufferers in adolescents show that young girls tend to have more anxiety than boys. [22] So that the next experiment, preferring young women with nomophobic symptoms as research subjects. Some psychotherapy techniques that can reduce nomophobic symptoms include the following:

\subsubsection{Cognitive Behavior Therapy (CBT)}

This therapy is carried out by restructuring cognitive and behavioral problems in individuals with problems (mal-adaptive or mental disorder), in this case, is nomophobia. The CBT process begins with the introduction of the concept or understanding of the beliefs and behavior patterns of anxious individuals, then restructuring the concepts that lead to changes in beliefs, emotions, and behavior for the better. The cognitive restructuring process leads to modification of the functions of thinking, analyzing, asking, acting, and deciding again. So that changes in thoughts, feelings, and actions that were originally negative will turn into positive ones.[22]

Experiments on the effectiveness of CBT therapy in nomophobic adolescent girls in Isfahan (Iran), show that CBT can reduce nomophobic symptoms and is recommended as a therapy for nomophobic sufferers.[23] 


\subsubsection{Adolescent-centered Mindfulness Therapy}

This therapy focuses on attention (mindfulness) carried out by adolescents. The purpose of attention is to refer to an individual's experience in achieving his knowledge, specifically, directed, at the moment, and free from internal and external judgments. Mindfulness practice will train awareness, change a person's thought patterns or attitudes and ideas, help develop and stabilize moods, strengthen emotional regulation, and strengthen the self-esteem of vulnerable adolescents. It also helps teens make positive changes in themselves by combining vitality with real experiences to achieve happiness and well-being.[24] This means that Adolescent-centered Mindfulness Therapy can build awareness, strengthen emotional regulation in adolescents with symptom nomophobia.

Experiments on the effectiveness of Adolescent-Centered Mindfulness Therapy in young women with nomophobia in Isfahan (Iran) show that this therapy reduces nomophobic symptoms and is recommended as a therapy for nomophobic sufferers.[23]

\subsubsection{Emotion-focused Therapy (ET)}

This therapy uses an emotional approach as the basis for self-construction and becomes the main determinant of organization in individuals so that handling focuses on emotions. The role of the therapist in helping individuals with problems (nomophobia) is to help people become aware of, accept, and understand their emotional experiences.

This therapy will be carried out in two phases, namely the Arriving and Leaving phase. The illustration is like a person who has to first arrive at a place, then can leave that place. A person cannot leave a place if he has never arrived at that place. In this therapy, there are three main principles, where the individual realizes his emotions (emotional awareness), emotion regulation, and transforms emotions.[25]

Experiments on the effectiveness of therapy for nomophobic sufferers, which have been conducted by Davoudi et al. (2019), show that emotion-focused therapy is recommended as an alternative to help regulate the emotions of young women with symptoms of nomophobia.[23]

\subsubsection{Family Therapy}

This therapy is more appropriate for people with nomophobia in children or teenagers. Research shows the effectiveness of family therapy in children who experience emotional problems including anxiety, depression, sadness, bipolar disorder, and suicide. Also, this therapy is effective for children who have eating disorders, sleep disorders, somat ic disorders, deviant behavior (eg ADHD, drugs, etc.).[26] Therefore, children or teenagers who are indicated with symptom nomophobia can use Family Therapy as an alternative to reduce or eliminate symptoms of nomophobia.

Several therapeutic techniques used in the psychological approach vary widely in dealing with anxiety (phobia). However, specific research is still needed to determine therapeutic techniques that change cognitive or mind-set, affective, and psychomotor aspects in nomophobic sufferers.

\subsection{Islamic Approach}

There is still limited research on Islamic therapeutic techniques in nomophobia sufferers. However, research on therapeutic techniques to overcome the symptoms of 
nomophobia, such as anxiety, hysteria, hyperactivity, and pain, has been conducted by several researchers. Islamic therapeutic techniques that can be done to overcome nomophobia include the following:

\subsubsection{Tazkiyah al-nafs (spiritual purification) and Riyadah al-nafs (spiritual exercise).}

Based on the results of research, it shows that spiritual purification (tazkiyah al-nafs) and spiritual practice (riyadah al-nafs) can reduce hysteria and can increase one's discipline.[27-29] So that nomophobia sufferers who experience hysteria can be given this therapy to reduce their hysterical behavior. Patients will also form a disciplined attitude if they implement riyadah al-nafs therapy.

\subsubsection{Sholat (prayer) dan Zikr}

Prayer and Zikr (remembering Allah) can reduce anxiety and symptoms or psychopathological symptoms and can form a better philosophical and Sufistic personality.[30] This means that this therapy can be applied to nomophobia who experience anxiety and other psychopathological symptoms

\subsubsection{Murotal Qur'an Therapy.}

Reading and listening to the verses of the Qur'an can reduce anxiety and pain and can increase immunity.[31-33] This means that people with nomophobia who experience pain (in the head, eyes, neck, back, etc.) can be done this therapy to reduce pain and build immunity.

\subsubsection{Wudhu (Hydrotherapy)}

Ablution is to purify oneself with water, so it is often called water therapy or Hydrotherapy. This water therapy has been researched and can reduce stress and insomnia (difficulty sleeping). [34, 35] This means, hydrotherapy can be used for nomophobia sufferers who have difficulty sleeping and who experience high self-tension (stress).

\section{Conclusion}

Based on the explanation above, several things can be ignored as follows:

a. Nomophobia is a mental illness that develops in society with the accelerated development of information technology.

b. Therapy with a psychological approach is not optimal for suppressing the development of mental illness (Nomophobia) in society, especially in the younger / productive generation (age $\pm 17-34$ years). This is because the increasing number of Nomophobia sufferers is increasingly massive, especially in Muslim families in Indonesia. Therefore, an Islamic approach is needed to solve the problem.

c. Research on Islamic therapy to deal with nomophobia specifically has not been proven empirically. However, the Islamic approach therapy is proven to overcome 
Nomophobia symptoms including pain, hysteria, and psychopathological behavioral symptoms that accompany nomophobic sufferers.

d. The Islamic therapeutic approach is proven to also form discipline and personality both philosophically and in Sufism.

e. Psychological and Islamic therapy approaches are alternatives for reducing nomophobia in society. 


\section{References}

[1] E. Turban, J. Outland, D. King, J. K. Lee, T.-P. Liang, and D. C. Turban, "Innovative EC Systems: From E-Government to E-Learning, E-Health, Sharing Economy, and P2P Commerce," in Electronic Commerce 2018, ed: Springer, 2018, pp. 167-201.

[2] E. M. En-Naimi and A. Zouhair, "Intelligent dynamic case-based reasoning using multi-agents system in adaptive e-service, e-commerce and e-learning systems," International Journal of Knowledge and Learning, vol. 11, pp. 42-57, 2016.

[3] D. Koroleva, "Always online: Mobile technology and social media usage by modern teenagers at home and at school," Вопросы образования, 2016.

[4] T. Bates and G. Poole, "Effective teaching with technology in higher education: Foundations for success," 2003.

[5] C. Yildirim and A.-P. Correia, "Exploring the dimensions of nomophobia: Development and validation of a self-reported questionnaire," Computers in Human Behavior, vol. 49, pp. 130-137, 2015.

[6] S. Y. Lee, "Examining the factors that influence early adopters' smartphone adoption: The case of college students," Telematics and Informatics, vol. 31, pp. 308-318, 2014.

[7] U. Dasiroh, S. Miswatun, Y. F. Ilahi, and N. Nurjannah, "FENOMENA NOMOPHOBIA DI KALANGAN MAHASISWA," MEDIUM, vol. 6, pp. 1-10, 2017.

[8] C.-Y. Lin, M. D. Griffiths, and A. H. Pakpour, "Psychometric evaluation of Persian Nomophobia Questionnaire: Differential item functioning and measurement invariance across gender," Journal of behavioral addictions, vol. 7, pp. 100-108, 2018.

[9] S. Muyana and D. A. Widyastuti, "NOMOPHOBIA (NO-MOBILE PHONE PHOBIA) PENYAKIT REMAJA MASA KINI," in Seminar Nasional Bimbingan Konseling Universitas Ahmad Dahlan, 2017.

[10] J.-H. Kim, "Psychological issues and problematic use of smartphone: ADHD's moderating role in the associations among loneliness, need for social assurance, need for immediate connection, and problematic use of smartphone," Computers in Human Behavior, vol. 80, pp. 390-398, 2018.

[11] A. L. S. King, E. Guedes, J. P. Neto, F. Guimarães, and A. E. Nardi, "Nomophobia: Clinical and demographic profile of social network excessive users," J Addict Res Ther, vol. 8, p. 2, 2017.

[12] K. Master, C. Kaur, A. Narasimhan, N. Mizrab, M. Ali, and R. Shaik, "Impact of electronic gadgets on psychological behavior of middle school children in UAE," Uni Emirates Arab. Gulf Medical Journal, vol. 5, pp. S54-S60, 2016.

[13] M. Pavithra, S. Madhukumar, and M. Mahadeva, "A study on nomophobia-mobile phone dependence, among students of a medical college in Bangalore," National Journal of community medicine, vol. 6, pp. 340-344, 2015.

[14] A. Chakrabarty, M. Tagiya, S. Pal, and N. H. H. Cuong, "Managing Psy chosomatic Disorders Related to Obsession and Addictions to Gadgets Through IoT Surveillance," in International Conference on Intelligent Computing and Communication Technologies, 2019, pp. 561-568.

[15] L. Jamir, M. Duggal, R. Nehra, P. Singh, and S. Grover, "Epidemiology of technology addiction among school students in rural India," Asian journal of psychiatry, vol. 40, pp. 30-38, 2019.

[16] C. Yemula, E. Musgrave, S. Ajmal, A. Khan, and R. Sesham, "G654 A clinic-based survey of sleep habits among teenagers with attention deficit hyperactivity disorder: impact of poor sleep and gender differences," ed: BMJ Publishing Group Ltd, 2019.

[17] J. S. Mendoza, B. C. Pody, S. Lee, M. Kim, and I. M. McDonough, "The effect of cellphones on attention and learning: The influences of time, distraction, and nomophobia," Computers in Human Behavior, vol. 86, pp. 52-60, 2018.

[18] D. M. Gezgin, O. Cakir, and S. Yildirim, "The Relationship between Levels of Nomophobia Prevalence and Internet Addiction among High School Students: The Factors Influencing Nomophobia," International Journal of Research in Education and Science, vol. 4, pp. 215-225, 2018. 
[19] G. Jilisha, J. Venkatachalam, V. Menon, and J. J. Olickal, "Nomophobia: A mixed-methods study on prevalence, associated factors, and perception among college students in Puducherry, India," Indian Journal of Psychological Medicine, vol. 41, pp. 541-548, 2019.

[20] I. Dalbudak, T. Yilmaz, and S. Yigit, "Nomophobia Levels and Personalities of University Students," Journal of Education and Learning, vol. 9, pp. 166-177, 2020.

[21] M. A. Olivencia-Carrión, R. Ferri-García, M. del Mar Rueda, M. G. Jiménez-Torres, and F. López-Torrecillas, "Temperament and characteristics related to nomophobia," Psychiatry research, vol. 266, pp. 5-10, 2018.

[22] S. G. Hofmann and M. W. Otto, Cognitive behavioral therapy for social anxiety disorder: Evidence-based and disorder specific treatment techniques: Routledge, 2017.

[23] R. Davoudi, G. Manshaee, and M. Golparvar, "Comparing the Effectiveness of AdolescentCentered Mindfulness with Cognitive Behavioral Therapy and Emotion-Focused Therapy on Emotion Regulation among Adolescents Girl with Nomo-Phobia," Journal of Health Promotion Management, vol. 8, pp. 16-25, 2019.

[24] B. Shayegh Borojeni, G. Manshaee, and I. Sajjadian, "The Effectiveness of Adolescentcentered Mindfulness Training and Cognitive Behavioral Therapy on Depression and Suicidal Ideation in Adolescent Girls With Bipolar II Disorder," مجله علوم اعصاب كانبين, vol. 5, pp. 175-184, 2019.

[25] L. S. Greenberg, "Emotion-focused therapy," Clinical Psychology \& Psychotherapy: An International Journal of Theory \& Practice, vol. 11, pp. 3-16, 2004.

[26] A. Carr, "The effectiveness of family therapy and systemic interventions for child-focused problems," Journal of family therapy, vol. 31, pp. 3-45, 2009.

[27] F. M. Sham, "Islamic psychotherapy approach in managing adolescent hysteria in Malaysia," Journal of Psychological Abnormalities in Children, vol. 4, pp. 1-4, 2015.

[28] S. Sulistiy ono and M. Iqbal, "THE EFFECTIVENESS OF “METODE 7 PENJERNIH HATI" TRAINING TO SENIOR HIGH SCHOOL STUDENT'S DISCIPLINE."

[29] M. P. Tjasmadi, "Pendekatan Agama Membaharui Kondisi Psikologis Siswa Terindikasi Nomophobia," Proceedings of the ICECRS, vol. 2, pp. 159-166, 2019.

[30] A. Afrinaldi, R. Amir, and M. Arif, "Psycho religious theraphy through prayers and dzikir in islamic psychology perpective," Scientific Journal of PPI-UKM, vol. 2, pp. 200-205, 2015.

[31] H. Hammad, "The role of the koran therapy on anxiety and immunity of hospitalized patients," Jurnal Ners, vol. 4, pp. 110-115, 2009.

[32] F. Faradisi, "Efektivitas terapi murotal dan terapi musik klasik terhadap penurunan tingkat kecemasan pasien pra operasi di pekalongan," Jurnal Ilmiah Kesehatan (JIK), vol. 5, 2012.

[33] S. Wahida, M. Nooryanto, and S. Andriani, "Terapi Murotal Al-Qur'an Surat Arrahman Meningkatkan Kadar $\beta$-Endorphin dan Menurunkan Intensitas Nyeri pada Ibu Bersalin Kala I Fase Aktif," Jurnal Kedokteran Brawijaya, vol. 28, pp. 213-216, 2015.

[34] M. Rinawati and Y. Isnaeni, "Pengaruh terapi wudhu sebelum tidur terhadap kejadian insomnia pada usia lanjut di Dusun Tilaman Wukirsari Imogiri Bantul Yogyakarta," STIKES'Aisyiyah Yogy akarta, 2012.

[35] D. K. Sari and M. W. Mahardyka, "Penerapan wudhu sebagai hydro therapy terhadap tingkat stres pada lansia upt pslu blitar di tulungagung," Journal Of Nursing Practice, vol. 1, pp. 24-32, 2017. 